\title{
The Europeanisation of Extradition: How Many Light Years Away to Mutual Confidence?
}

\author{
THEODORE KONSTADINIDES*
}

\subsection{Introduction}

The objective set for the Union to become an area of freedom, security and justice has led, amongst else, to abolishing extradition between Member States and replacing it with a simplified system of 'surrender between judicial authorities'. Following the September 2001 terrorist attacks in New York, and having considered the potential impact on the fight against crime and terrorism, the Heads of State and Government of the European Union, the President of the European Parliament, the President of the European Commission, and the former High Representative for the Common Foreign and Security Policy jointly called for a new system that would make it easier for justice to be administered across the EU through the enforced transfer of persons from one Member State to another. The draft legislative resolution on the Commission proposal for a Council Framework Decision on the European Arrest Warrant (EAW) ${ }^{1}$ was adopted on 13 June 2002 by the Council, establishing a pan-European warrant for search, arrest, detention and surrender to the judicial authority of the issuing country. ${ }^{2}$ As a consequence, in 2004 the EAW gradually replaced extradition between Member States. $^{3}$

Undeniably, the Framework Decision on the $\mathrm{EAW}^{4}$ has added impetus to the EU counter-terrorism response, which since and the terrorist bombings in Madrid (March 2004) and London (July 2005) has expanded incrementally through the adoption of a panoply of measures. ${ }^{5}$ At the time of writing, not only has the EAW been implemented by all the Member States but it is operational in most cases. The

\footnotetext{
* University of Surrey. This chapter constitutes a modified and updated version of an article entitled 'The Perils of the Extradition Procedures in the EU: Mutuality, Fundamental Rights and Constitutional Guarantees' (2007) 14 Maastricht Journal of European and Comparative Law 179-200. I am indebted to Leslie Blake and Valsamis Mitsilegas for their constructive comments on earlier versions of this chapter. Many thanks to Maria Bergström, Vladimir Bastidas and Jane Reichel for their observations on the version of this chapter that was presented as a short paper at the Centre of European Integration, Faculty of Law, University of Stockholm. I am grateful to Natasha Gouseti for her support. Any errors or omissions are obviously entirely mine.

${ }^{1}$ Commission Proposal: OJ C 332 E, 27.11.2001; COM (2001) 522; Bull. 9-2001.

${ }^{2}$ The Framework Decision was adopted under Articles 31 (a) and (b), and Article 34(2) (b) TEU.

${ }^{3}$ Article 34 TEU determines the legal effects of Third Pillar framework decisions. Almost like EC Directives, they are binding on the Member States as to the result to be achieved, and they are to be implemented through more concrete national measures. According to Article 34 of the Framework Decision, Member States should have taken the necessary measures to comply with the provisions of the Framework Decision by 31.12.2003. Italy's implementation was not completed until April 2005. See Report of the Commission based on Article 34 of the Council Framework Decision of 13 June 2002 on the European Arrest Warrant and the Surrender Procedures between Member States (revised version) COM (2006) 8 final. The first report of the Commission was issued in February 2005, COM (2005) 63.

${ }^{4}$ Council Framework Decision on the European Arrest Warrant and the Surrender Procedures between Member States, [2002] OJ L190/1 (hereafter called the Framework Decision on the EAW).

${ }^{5}$ See Commission Activities in the Fight against Terrorism, 12.03.2007, MEMO/07/98. See also C. Eckes' chapter in this volume.
} 
traditional cooperation between Member States has been replaced by an EU-wide system of 'free movement' of judicial decisions in criminal matters, covering both pre-sentence and final decisions, acting within an area of freedom, security and justice. This transition, however, has not occurred without hiccups caused by constitutional difficulties. It will be noted below that a period of legal uncertainty (with reference to the full application of the EAW) arose during 2005 and 2006 due to transposition difficulties of the Framework Decision in certain Member States. This stemmed from their own constitutional requirements. Although these problems have, in the majority of cases been overcome, a handful of Member States still exercise the right to limit the Framework Decision's substantive scope.

This chapter discusses the modernisation or, dare we say, Europeanisation of the extradition procedures by focusing upon the modernisation of the surrender procedure by the Framework Decision on the EAW as well as upon its implementation by the Member States. The centre of attention is on mutual recognition as an alternative to harmonisation. ${ }^{6}$ To achieve this we must first examine the two major reforms introduced by the Framework Decision on the EAW, namely the abolition of the 'double criminality' test for the categories of offences listed in Article 2(2) of the Framework Decision and the limited grounds for refusal of execution, especially the rule against surrendering nationals. Such a refusal cannot now rest on any human rights considerations, despite its constitutional premise in a number of cases. Second, this chapter will explore certain problem areas. It will provide a commentary on the paradox that, while the Framework Decision dispenses with verification of the double criminality test for the categories of listed offences, it leaves the definition of those offences (and the penalties applicable in each case) to the issuing Member State. And in accordance with Article 1(3) of the Framework Decision the Member State must respect fundamental rights as enshrined in Article 6 TEU as well as the principle of legality. The present author argues that 'mutual recognition' does not necessarily imply mutual trust. The chapter concludes by offering an insight into the changes that have occurred since the coming into force of the Treaty of Lisbon, where Communitarisation has taken over the Union's Third Pillar.

\subsection{The Modernisation of the Surrender Procedure}

\subsubsection{Implementation of the Principle of Mutual Recognition}

The Framework Decision on the EAW is the first instrument in the area of freedom, security and justice to be adopted following the principle of mutual recognition. In opposition to any insistence on uniformity through approximation, the principle of 'mutual recognition' constitutes the least contentious method for integration. Mutual recognition does not create common substantive rules. It rather depends upon the Member States' tolerance of the diversity characterizing national legal systems. It further encourages cooperation between them through mutual trust and recognition of each other's practices. Mutual recognition was first applied by the Court in relation to the Community Pillar on product requirements case law as collateral to Community harmonization during the construction of the internal

\footnotetext{
${ }^{6}$ For the purpose of this chapter any reference to 'harmonisation' is taken to mean harmonisation of substantive law (to address the abolition of dual criminality) and not harmonisation of the rights of the defendant. These are different fields of law and serve different purposes.
} 


\section{PROOF VERSION}

market. $^{7}$ Mutual recognition gradually expanded to cover other Community policy areas and became an additional limitation on national competence. ${ }^{8}$

In line with the Tampere European Council (1999) and the succeeding Hague Programme (2004) for strengthening freedom, security and justice, ${ }^{9}$ the EU Institutions implemented the principle of mutual recognition in the former Third EU Pillar, so as to bring about direct execution of final criminal decisions in the whole territory of the European Union. Member States were encouraged to show mutual trust in their criminal justice systems to such an extent that each one would acknowledge and trust the criminal law in force in other Member States, even in cases where the outcome would be different to that applied in its own domestic legislation. Accordingly, a measure arising from a judgment of a Member State ought to be automatically accepted and should produce the same effects in all Member States of the Union.

Furthermore, the principle of mutual recognition appeared perfectly apt to ensure that an individual tried in a Member State for a particular criminal offence should not be judged a second time for the identical offence, either in the state in which s/he offended or in any other Member State of the Union. This is identified in international law as the ne bis in idem principle. ${ }^{10}$ The Framework Decision on the EAW refers implicitly to the principle as constituting one of the grounds for optional nonexecution of the EAW. Hence, according Article 4(6), an executing judicial authority may refuse to execute the EAW "where the person who is the subject of the European arrest warrant is being prosecuted in the executing Member State for the same act as that on which the European arrest warrant is based'. In Klaus Bourquain, the Court considered the conditions governing the applicability of the ne bis in idem principle as enshrined in Article 54 of the Convention implementing the Schengen Agreement (CISA):

Article 54 of the CISA, applied to a judgment in absentia delivered in accordance with the national legislation of a Contracting State or to an ordinary judgment, [and] necessarily implies that the Contracting States

\footnotetext{
${ }^{7}$ Case 120/78, Commission Rewe-Zentrale AG v. Bundesverwaltung für Branntwein (Cassis de Dijon) [1979] ECR 649. For further discussion see M. P. Maduro, We the Court: The European Court of Justice \& The European Economic Constitution (Oxford: Hart Publishing, 1997), pp. 33, 131-136.

${ }^{8}$ See for instance, the Court's horizontal approach to the recognition of diplomas in relation to the freedom of establishment of EU Citizens in Case 340/89, Vlassopoulou [1991] ECR 2461 and its codification in Directive 89/48/EEC on the mutual recognition of diplomas (later replaced by Directive 2005/36).

${ }^{9}$ The Presidency Conclusions at the Tampere European Council, 15 and16 October 1999. Available online at http://www.europarl.europa.eu/summits/tam_en.htm; The Presidency Conclusions at the Brussels European Council, 4 and 5 November 2004. Available online at http://www.consilium.europa.eu/uedocs/cmsUpload/14292-r1.en04.pdf.

${ }^{10}$ Translated from Latin as 'not twice for the same'. It is often referred to as 'the double jeopardy principle'. (See C.J.M. Safferling, Towards an International Criminal Procedure (New York: Oxford University Press, 2001), pp. 319-323). A sentenced person will not be returned to the issuing State if s/he has already been tried for the same offence. See to that effect: Article 4, Protocol 7 ECHR and Article 54 of the Convention implementing the Schengen Agreement of 14 June 1985 between the Governments of the States of the Benelux Economic Union, the Federal Republic of Germany and the French Republic on the gradual abolition of checks at their common borders (2000) OJL 19. See further M. Fletcher, 'Some Developments to the ne bis in idem Principle in the European Union: Criminal Proceedings Against Hüseyn Gözütok and Klaus Brügge', Modern Law Review, 66 (5) (2003), 769; J.A.E. Vervaele, 'The Transnational ne bis in idem Principle in the EU: Mutual Recognition and Equivalent Protection of Human Rights', Utrecht Law Review, 1 (2) (2005), 100; M. Wasmeier, 'The Development of ne bis in idem into a transnational fundamental right in EU law: Comments on Recent Developments', European Law Review, 31 (4) (2006), 565.
} 


\section{PROOF VERSION}

have mutual trust in their criminal justice systems and that each of them recognises the criminal law in force in the other Contracting States even when the outcome would be different if its own national law were applied. ${ }^{11}$

The application of the ne bis in idem principle, as set out in Article 54 of the Schengen Convention, was adopted by the Council in March 2009. The Council proposed a framework decision to that effect in order to avoid the adverse consequences arising from parallel proceedings in Member States. ${ }^{12}$ Extradition was only mentioned once, namely in connection with the relevant criteria which competent authorities need to consider in order to reach consensus. It relates to 'the location of the suspected or accused persons and possibilities for securing their surrender or extradition to other jurisdictions'. ${ }^{13}$

EU Institutions have not only emphasized the significance of enhanced mutual recognition of judicial decisions and judgments as a means of facilitating co-operation between authorities and the judicial protection of individual rights. ${ }^{14}$ They have also emphasized that the convergence among the different forms of cooperation will necessitate the approximation of national legislation. Textually, the trend among Member States to establish a simplified and efficient procedure, founded on mutual confidence and respect of the integrity of each other's constitutions and judicial systems, was manifested in former Articles 31(a), (b) and 34(2)(b) TEU. ${ }^{15}$ These Treaty provisions set out the first series of targets to bring about judicial cooperation in criminal matters, the facilitation of extradition, and the adoption of framework decisions for the purpose of approximating the laws and regulations of Member States.

\footnotetext{
${ }^{11}$ Case C-297/07 Klaus Bourquain (2008) ECR 00000. The case concerned a soldier in the French Foreign Legion who in 1960 was sentenced to death in absentia after found guilty of desertion and murder. In 2002, the Regensburg Public Prosecutor's Office in Germany, where Bourquain had taken refuge, charged him with murder in respect of the same acts. The Regional Court decided to stay the proceedings and to make a preliminary reference to the Court as to whether a person whose trial has been finally disposed of in one Contracting Party may be prosecuted in another Contracting Party for the same act when, under the laws of the sentencing Contracting Party, the sentence imposed on him could never have been enforced. See also Case C-288/05, Jürgen Kretzinger; Case C-491/07, Vladimir Turanský (2008) ECR 00000.

12 Proposal for a Council Framework Decision on Prevention and Settlement of Conflicts of Jurisdiction in Criminal Proceedings, 27.03.2009, 8013/09 COPEN 62,

${ }^{13}$ According to the proposal (para 10): 'If consensus cannot be reached, the Member States should retain their right to initiate or continue criminal proceedings for any criminal offence which falls within their national jurisdiction. Where consensus has been reached on the concentration of criminal proceedings in one Member State, the competent authorities in the other Member State should act in a way that is compatible with that consensus.'

14 'Communication from the Commission to the Council and the European Parliament - Mutual recognition of Final Decisions in criminal matters' COM (2000) 0495; 'Green Paper on the approximation, mutual recognition and enforcement of criminal sanctions in the European Union' COM (2004) 334; 'White Paper on exchanges of information on convictions and the effect of such convictions in the European Union' COM (2005) 10; 'Communication from the Commission to the Council and the EP on the mutual recognition of judicial decisions in criminal matters and the strengthening of mutual trust between Member States' COM (2005) 195; Council Framework Decision 2005/214/JHA; Council Framework Decision 2006/783/JHA.

${ }^{15}$ In the Treaty of Lisbon, Judicial Cooperation in Criminal Matters consists of Chapter 4, Articles 82 85 TFEU. Article 82 TFEU sets the tone: 'Judicial cooperation in criminal matters in the Union shall be based on the principle of mutual recognition of judgments and judicial decisions and shall include the approximation of the laws and regulations of the Member States...'
} 


\section{PROOF VERSION}

As mentioned at the beginning, the Framework Decision on the EAW ${ }^{16}$ constitutes the first concrete measure in the field of European criminal law implementing the principle of mutual recognition. It has replaced all multilateral extradition agreements based on public international law and EU or Schengen extradition arrangements. Already in Article 1(2), the Framework Decision points to the principle of mutual recognition as the preliminary way of executing any EAW. To put it in the Commission's phrasing, 'the arrest warrant is the first and most symbolic measure applying the principle of mutual recognition'. ${ }^{17}$ Given the breadth of the areas that it captures and the momentous time at which it was introduced, it has been characterized as the "star rule on judicial cooperation in criminal matters' ${ }^{18}$ and as 'an important procedural instrument in the fight against terrorism'. ${ }^{19}$ In its 2007 Report on the implementation (since 2005) of the Framework Decision, the Commission states that 'the arrest warrant is a success'. ${ }^{20}$ The Commission not only mentions the fact that the total number of requests exchanged between Member States has risen substantially but it also notes that the EAW surrenders have been effected within shorter time limits than in the previous two years.

\subsubsection{Abolition of the Double Criminality Test}

Contextually, the EAW covers almost every offence punishable in the Member States by a custodial sentence or a detention order for a maximum period of at least three years and as they are defined by the law of the issuing state. ${ }^{21}$ It does not in itself, provide for any punishments. It is rather aimed at simplifying the extradition procedures for suspected criminals within the territory of the European Union by creating a list of substantive criminal offences, grouped into designated areas. According to Article 1(1) of the Framework Decision, the EAW is a judicial decision. The exclusion of the executive power from the process was justified by the objective of breaking free from the political considerations that cause delay in the extradition procedure. When, therefore, a crime is included within a designated 'criminal area' (e.g. illegal human trafficking, ${ }^{22}$ money laundering, ${ }^{23}$ drug importation ${ }^{24}$, terrorism ${ }^{25}$ ), the issuing Member State's judicial authorities may contact their counterparts in the executing Member State directly to achieve the surrender of a person within ten or

\footnotetext{
${ }^{16}$ Council Framework Decision on the European Arrest Warrant and the Surrender Procedures Between Member States (13 June 2002) (2002/584/JHA). See also R. Blextoon (ed.), Handbook on the European Arrest Warrant (Cambridge University Press, 2004).

${ }^{17}$ Report of the Commission based on Article 34 of the Council Framework Decision of 13 June 2002 on the "European Arrest Warrant and the Surrender Procedures between Member States", COM (2005) 63, p.2.

${ }^{18}$ M. Jimeno-Bulnes, 'European Judicial Cooperation in Criminal Matters', European Law Journal, 9 (2003), 614.

${ }^{19}$ M. Jimeno-Bulnes, 'After September $11^{\text {th }}$ : The Fight Against Terrorism in National and European Law. Substantive and Procedural Rules: Some Examples', European Law Journal, 10 (2004), 235.

20 'Report from the Commission on the Implementation since 2005 of the Council Decision of 13 June 2002 on the European Arrest Warrant and the Surrender Procedures between Member States', (11.08.2007) COM (2007) 407 final.

${ }^{21}$ See Article 2(2) of the Framework Decision for the list of offences, which rise to surrender pursuant to a EAW.

${ }^{22}$ King's Prosecutor (Brussels) v. Armas [2006] 1 All E.R. 647.

${ }^{23}$ Hunt v. Belgium [2006] EWHC 165.

${ }^{24}$ Hall v. Germany [2006] EWHC 462; Parasiliti - Mollica v. Deputy Public Prosecutor (Messina) [2005] EWHC 3262.

${ }^{25}$ Bundesverfassungsgericht (German Constitutional Court), decision of 18 July 2005 (2 BvR 2236/04) on the German European Arrest Warrant Law.
} 


\section{PROOF VERSION}

sixty days (depending on whether the arrested person consents to being surrendered) in order to serve there the custodial sentence or detention order passed against him/her. Member States cannot refuse to surrender to another Member State any of their own citizens on the grounds that they are nationals. ${ }^{26}$ This implies that if a Member State issues a EAW against a national of another Member State, then the latter must surrender its national to the former without consideration of the 'double criminality rule'.

Contrary to most extradition treaties, the Framework Decision on the EAW has removed previous extradition safeguards. It has abolished both the traditional 'double criminality rule' of the thirty-two offences listed in Article 2 (2) and - where the arrested person consents - the 'specialty rule'. ${ }^{27}$ The former, (double criminality rule) constitutes a requirement that the offence in question constitutes an offence both under the law of the state where the alleged offence occurred and of the requesting state seeking extradition. The latter rule (specialty rule), is a customary international law practice, which requires states to undertake to prosecute the alleged conduct of the suspect whose extradition is sought only in respect to extraditable offences set out in the extradition request. ${ }^{28}$

Under the system introduced by the Framework Decision, the double criminality rule has been reserved only for offences other than those designated in Article 2 of the Framework Decision. ${ }^{29}$ Although the EAW applies without the need to fulfil the condition of the double criminalisation of an act, in some Member States the old test of double criminality may coincide with the operation of the EAW. For instance, under section 64(3) (b) of the UK's Extradition Act $2003^{30}$ a person's conduct:

....also constitutes an extradition offence in relation to the category 1 territory (i.e. all EU countries operating the European Arrest Warrant System) if ... the conduct would constitute an offence under the law of the relevant part of the United Kingdom if it occurred in that part of the United Kingdom.

In Hosseini v. France ${ }^{31}$ the two Member States concerned (France and the UK) agreed that the conduct of illegal human trafficking constituted an offence in France and would have constituted an offence had it occurred in England. Therefore the conduct alleged in the warrant amounted to extraditable offence pursuant to s. 64(3) of the Extradition Act 2003. In England, the High Court took into account the EAW and concluded:

...the relevant question, therefore, is whether his [Hosseini's] extradition pursuant to the 2003 Act would be in accordance with the law; and, as I have already indicated, it plainly would be. The starting

\footnotetext{
${ }^{26}$ See Articles $3 ; 4 ; 5 ; 6 ; 8 ; 9 ; 10 ; 11 ; 12 ; 17 ; 26 ; 27$ of the Framework Decision as regards details on operation and procedures of the European Arrest Warrant.

${ }^{27}$ Article 13(1).

${ }^{28}$ See Case C-388/08 PPU, Criminal Proceedings against Leymann and Pustovarov [2008] ECR 00000. The case involved a change to the description of the facts in the course of the proceedings (the class of narcotic drugs). The Court stressed that the alteration of the description of the illegal trafficking offence from hashish to amphetamines was not capable of being characterized as another offence and therefore triggering the specialty rule.

${ }^{29}$ Article 2(4) provides: 'For offences other than those covered by paragraph 2, surrender may be subject to the condition that the acts for which the European arrest warrant has been issued constitute an offence under the law of the executing Member State, whatever the constituent elements or however it is described.'

${ }^{30}$ The Extradition Act (2003) entered into force on January 12004.

${ }^{31}$ Hosseini v. France [2006] EWHC 1333.
} 


\section{PROOF VERSION}

point under the 2003 Act is the issue of a European arrest warrant by a judicial authority in another member state. Consistently with the Council Framework Decision of 13 June 2002 which it implements, the 2003 Act recognises and gives effect to the issue of the warrant. ${ }^{32}$

The double criminality rule has long been considered by Member States as the core feature of extradition law. Its abolition has created practical problems that render the application of the EAW open to discussion. ${ }^{33}$ One example is when the warrant does not provide particulars of the provision of national law that renders the conduct of the arrested person an offence under that law. ${ }^{34}$ In Hunt v. Belgium ${ }^{35}$, for instance, the Administrative Court of England and Wales ruled that the warrant should contain a statement that 'the person, in respect of whom the warrant was issued, was accused in the category 1 territory of the commission of an offence specified in the warrant.' In this case the warrant failed to conform to the requirements of the British Extradition Act 2003 as it did not identify the provision of Belgian legislation under which the suspect's conduct was alleged to constitute an offence. Thus the warrant had to be quashed. In Armas, ${ }^{36}$ on the other hand, the warrant was clear as the nature and classification of the offence in question. This offence was identified as 'systematic illegal immigration' (a listed offence). Nonetheless, the warrant had to be quashed because some of the offences of the person sentenced (in absentia) had occurred in the UK. Thus the offender could not be surrendered to Belgium under section 65(2)(a) of the British Extradition Act 2003, which states that 'the conduct constitutes an extradition offence in relation to the category 1 territory if... the conduct occurs in the category 1 territory and no part of it occurs in the United Kingdom.' 37

The use of the double criminality test is still widespread, especially in cases involving errors in the EAW procedure. The consequence of accuracy and attention to detail in the preparation of a EAW was recently stressed by the Judicial Committee of the House of Lords in Hilali3 ${ }^{38}$. In 2004, a EAW was issued by Spain seeking the surrender of Mr Farid Hilali for the purpose of his prosecution for the offence of participation in a terrorist organization and involvement in a terrorist conspiracy to commit the 9/11 terrorist attacks. An extradition order was made by Senior District Judge Workman in 2005 in the Magistrates' Court under Section 21(3) of the (British) Extradition Act 2003 ordering Mr Hilali's extradition to Spain. The information in the EAW referred to a link between the claimant and Mr Barakat Yarkas. Mr Yarkas who was portrayed as a key figure in the terrorist conspiracy was, some time after the EAW was issued against Mr Hilali, acquitted by the Supreme Court in Spain because of inadmissible evidence. While remanded in custody, Mr Hilali claimed that, notwithstanding the lawfulness of the original extradition order, this change of

\footnotetext{
${ }^{32}$ Per Lord Justice Richards in Hosseini v. France [2006] EWHC 1333. para 47.

${ }^{33}$ E.V. Sliedregt, 'The Principle of Dual Criminality and the European Arrest Warrant' in N. Keijzer and E.V. Sliedregt (eds.), European Arrest Warrant in Practice (Cambridge University Press, 2009). Available at SSRN: http://ssrn.com/abstract=1310194 (last browsed on 31 January 2009).

${ }^{34}$ Hall v. Germany [2006] EWHC 462.

${ }^{35}$ Hunt v. Belgium [2006] EWHC 165

${ }^{36}$ [2006] 1 All E.R. 647. The question in this case was whether a request by Belgium for the extradition of a fugitive offender could be successfully brought under section 65 of the British Extradition Act (2003) when part of the appellant's conduct specified in the European Arrest Warrant took place in the UK.

${ }^{37}$ Other cases concerning problems arising from the information contained within the warrant include Peter Von Der Pahlen v. Austria [2006] EWHC 1672; Gersine Nazaret Raoul Fitzpatrick v. Office of the Public Prosecutor of the County Court of Montlucon, France [2006] EWHC 760; Dabas v. Spain [2007] 2 AC 31.

${ }^{38}$ Hilali v. Governor of Whitemoor Prison (Application for a Writ of Habeas Corpus) [2008] UKHL 3.
} 


\section{PROOF VERSION}

circumstances was fundamental and undermined the basis on which his extradition order had been made and was in breach of the specialty rule. He therefore sought a writ of habeas corpus, as the appropriate remedy against his continued detention which, although allowed by the High Court, ${ }^{39}$ was later rejected by the House of Lords. Lord Hope stressed that an inquiry into the evidential basis on which the EAW is sought runs counter to the principle of mutual recognition and is impermissible. Hence, while the decision of whether the alleged crime specified in the EAW constitutes an extradition offence is reserved by the courts of the executing state, the evidence on which it was based and its admissibility are entirely matters for the court of the issuing state. ${ }^{40}$

The mischief and confusion that arose in this case were related, first, to the fact that the Spanish authorities did not complete the EAW correctly, setting out only a brief description of the offence and giving no more than the particulars required by Article 8 of the Framework Decision on the EAW. By contrast, the information in the EAW concerning the relevant evidence was 'long, extraneous and potentially confusing' ${ }^{41}$ and was developed 'at inordinate length', including 'much irrelevant material' ${ }^{42}$ Second, in making the order of extradition of Mr Hilali, the District Judge at the Magistrates Court did not apply his mind to the question whether that participation in a terrorist organisation was not a listed offence but decided the case on the grounds that the alleged conduct amounted to an 'extradition offence' under the British Extradition Act 2003. The application of the double criminality test was more convenient to the District Judge who set out to make the extradition order once he was satisfied that had the offence occurred in England, it would have been classified as a conspiracy to commit the offence of murder of persons in America. It is further noteworthy that, according to Lord Hope, the district judge had never been asked to comment on whether participation in a terrorist organisation constitutes an extradition offence ${ }^{43}$, not even, if he were to be satisfied that murder (a listed offence) includes, by implication, conspiracy to murder. Third, one cannot overlook the legislative obtuseness characterizing the implementation of the EAW in the UK, effectively criticized by Spencer in $2008 .^{44}$

Mr Hilali's appeal raised delicate hypothetical questions regarding the degree of cooperative relationships that can be sustained between Member States in postextradition matters: in particular, whether, following the extradition of a person, an executing state has jurisdiction to order the authorities of a requesting state either to detain him only in relation to the offences for which he was extradited or alternatively to demand his return on the grounds that he is being (or is likely to be) deprived of the specialty rule. While British courts act under statute and do not possess the competence to intervene and give directions to a court of another sovereign state, they can, under Section 54 of the Extradition Act 2003, request the judicial authorities of an issuing state to make a request for an extradited person to be dealt with for an offence for which he was not surrendered. Furthermore, an alleged breach of the

\footnotetext{
${ }^{39}$ Hilali v. Governor of Whitemoor Prison [2007] EWHC 939, paras 40, 80, 81.

${ }^{40}$ See more recently Kucera v. Czech Republic [2008] EWHC 414.

${ }^{41}$ Hilali v. Governor of Whitemoor Prison [2007] EWHC 939, para 80.

${ }^{42}$ Hilali v. Governor of Whitemoor Prison (Application for a Writ of Habeas Corpus) [2008] UKHL 3, para 26.

${ }^{43}$ Ibid., para 27.

${ }^{44}$ J.R. Spencer, 'The Drafting of Criminal Legislation: Need it be so Impenetrable?', Cambridge Law Journal, 67(3) (2008), 593. See also L.W. Blake, T. Sinnamon and J. Pointing, 'Over-regulation and Suing the State for Negligent Legislation', Statute Law Review, (2007), 1.
} 
specialty rule should only be resolved by way of appeal to any higher court of the issuing state and, if necessary, to the European Court of Justice.

These considerations, however, were not relevant to Mr Hilali's case. Thus, the House of Lords dismissed his application for judicial review and affirmed the Magistrates' Court order of 2005 for the claimant's extradition to Spain but on different grounds to the ones stated in the EAW. Since participation in a terrorist organization is not a listed offence as per Article 2 (2) of the Framework Decision on the EAW, the House of Lords held that the information in the EAW on the alleged offence had sufficiently particularized the type of conduct that is contemplated by the new surrender procedure. Hence, the double criminality test was applied in accordance with Article 64(3) of the British Extradition Act 2003. The offences of conspiracy to commit the offence of murder of persons in the United States and of destroying, damaging or endangering the safety of aircraft, contrary to section 2 of the Aviation Security Act 1982, were the only offences in respect of which Mr Hilali could be extradited.

It is apparent that mutual recognition has not overridden the rule of double criminality. Even in relation to listed offences, the principle of double criminality has not been entirely abandoned by all Member States. At the time of writing, Slovenia and Italy still have it in place against requests based on acts which do not constitute criminal offences, therefore attributing more weight to the wishes of the executing state than the issuing state. What is more, Germany, Belgium, the UK, and Estonia have adopted a restrictive approach in relation to offences committed partly in their national territory. In any case, Article 2(2) of the Framework Decision, lists thirty-two offences as to which the double criminality test no longer applies, but without, however, defining their content, or doing so only in a vague fashion. Additionally, the suppression of the double criminality requirement, has failed to eliminate mistrust between Member States, especially with reference to detention facilities, effectiveness of their legal systems, and procedural guarantees. ${ }^{45}$

\subsubsection{Extradition of Own Nationals in Europe}

The most controversial measure under the system introduced by the EAW is that created by the obligation of a Member State to extradite its own nationals at the request of another Member State, even for offences that are not punishable in the former. ${ }^{46}$ The non-surrender of own nationals 'has its origins in the sovereign authority of the ruler to control his subjects, the bond of allegiance between them, and the lack of trust in other legal systems'. ${ }^{47}$ Moreover, it constitutes an exceptionally delicate issue in extradition law, ${ }^{48}$ employed sometimes by governments as a political

\footnotetext{
${ }^{45}$ See Council of the European Union, 'Replies to Questionnaire on Quantitative Information on the Practical Operation of the European Arrest Warrant - Year 2008' 9734/1/09 REV 1.

${ }^{46}$ See Opinion of the High Court of Justice delivered by Lord Justice Clerk in Antonio La Torre v. Her Majesty's Advocate [2006] HCJAC 56: 'While under other UK legislation membership of certain terrorist organisations might be an offence per se, as in the case of certain Irish organisations for example, membership of an Italian organisation was not an offence known to the law of Scotland.'

${ }^{47}$ Z. Deen-Racsmány and R. Blekxtoon, 'The Decline of the Nationality Exception in European Extradition? The Impact of the Regulation of (Non-) Surrender of Nationals and Dual Criminality under the European Arrest Warrant', European Journal of Crime, Criminal Law and Criminal Justice, 13 (2005), 317.

${ }^{4}$ Although Member States such as the UK, Spain and the Netherlands have been surrendering nationals for a long time, for most member states surrender of nationals to stand trial in another Member State constitutes a novelty. See para 36 of the Austrian Criminal Code (1852) and para 9 of the German Criminal Code.
} 


\section{PROOF VERSION}

technique to revive patriotism. ${ }^{49}$ Against this, Articles 3 and 4 of the EAW do not recognise the long-standing absolute sovereign right to refuse extradition of a Member State's own subjects. Instead, the Framework Decision only refers to the 'requested person' without distinguishing his/her nationality. It encompasses the principle that since EU citizens enjoy the benefits of free movement across the Union, they are equally responsible for their acts before the national courts of all Member States.

Article 6 of the 1957 European Convention on Extradition identified with the concerns of the Member States and allowed room for national authorities to refuse extradition on the grounds that the suspected person was a national of the requested state. This bar to extradition was ended in 1996 when Article 7 of the European Convention on Extradition provided that:

1. Extradition may not be refused on the ground that the person claimed is a national of the requested Member State within the meaning of Article 6 of the European Convention on Extradition.

2. When giving the notification referred to in Article 18 (2), any Member State may declare that it will not grant extradition of its nationals or will authorize it only under certain specified conditions.

Although Article 4(6) of the Framework Decision leaves room for non-execution in the case of a custodial sentence or a detention order, in principle, there is no exception for the surrender of a state's own nationals, but only an exception which can be made in domestic law 'where the requested person is staying in, or is a national or a resident of the executing Member State and that State undertakes to execute the sentence or detention order in accordance with its domestic law. ${ }^{50}$ Thus, under the Framework Decision and national implementing Acts there is some scope for Member States to safeguard their own nationals from prosecution in another Member State. Still, the Framework Decision makes a stand against the refusal of a Member State to extradite its own citizens and prevents a national court from protesting against a crime that is not punishable under its own legal system. This inability contravenes the guarantees safeguarded by the constitutions of many Member States. For instance, the Austrian Extradition and Mutual Legal Assistance Act (1980) prohibits the extradition of its own nationals. ${ }^{51}$ The same prohibition also appears in Article 55 of the Constitution of the Republic of Poland (1997); Article 16 (2) of the German Constitution (1949) ${ }^{52}$ and Article 11 of the Cypriot Constitution (1960). ${ }^{53}$ As a result of the new obligation to surrender own nationals the EAW has come under attack by certain national courts arguing that the Framework Decision was drafted without

\footnotetext{
${ }^{49}$ See M. Plachta, 'Recent Developments in the Extradition Law', 2 Yearbook of Polish European Studies, 93 (1998), 109.

${ }^{50}$ Note that the Framework Decision does not define the terms of 'staying' and 'residence' in the executing Member State. This is a relevant criterion insofar as the exception - ground for optional nonexecution of the EAW under Article 4(6) is concerned. See Case C-66/08, Szymon Kozlowski [2008] ECR 00000; Case C-123/08 Wolzenburg, Advocate General's Opinion, 24 March 2009. Advocate General Bot stressed that the duration of an individual's stay in the executing Member State must be sufficient in order to establish a link with the executing Member State in order to make the serving of a prison sentence there necessary for the person's rehabilitation. See the Law Societies, Joint Brussels Office Update Series, Developments from the ECJ, March 2009. Available at www.lawsociety.org.uk.

${ }^{51}$ Art. 12 ARHG (Auslieferungs - und Rechtshilfegesetz), Federal Law Gazette No 529/1979.

${ }^{52}$ Basic law for the Federal Republic of Germany written on May 231949 and amended by the Unification Treaty of August 311990.

${ }^{53}$ Available at www.kypros.org/Constitution/English/
} 


\section{PROOF VERSION}

contemplation of national criminal codes or constitutional provisions and therefore its application is impracticable.

The first national reaction to the new extradition procedures came from Poland on 27 April 2005. Despite the fact that the judicial authorities in Poland had issued 150 warrants (in the period May 2004 - November 2004) of which thirty were executed, the Polish Constitutional Tribunal (Trybunal' Konstytucyjny) decided that surrender of Polish nationals was incompatible with the Polish Constitution. ${ }^{54}$ The Constitutional Tribunal examined a question of law referred by the Gdańsk Regional Court regarding the constitutionality of Article 607t (1) of the Criminal Procedure Code (1997) and its compatibility with Article 55 (1) of the Constitution of the Republic of Poland. Article 607t (1) of the Criminal Procedure Code permits the surrender of a Polish citizen to the authorities of another Member State of the European Union in response to the EAW ${ }^{55}$ By contrast, Article 55 (1) of the Polish Constitution makes it clear that 'the extradition of a Polish citizen shall be forbidden, ${ }^{56}$.

The Polish Tribunal emphasized that it retains the competence to examine the conformity of normative acts of the Constitution as well as legal provisions implementing EU legislation. It highlighted the fact that the Polish Constitution bestows certain rights and obligations on Polish citizens. National citizenship, according to the Polish Tribunal, is essential for assessing the legal status of an individual and EU Citizenship can only 'complement' it and not 'replace' it (Article 20 TFEU). In the same manner, EU Citizenship was held not to diminish national constitutional guarantees linked to the individual's fundamental rights. However, the Polish tribunal recognized its obligation under Article 9 of the Polish Constitution to implement secondary EU legislation and the provisions of the Accession Treaty. It also acknowledged its obligation to interpret national legislation in conformity with EU law, albeit within certain limits (i.e. to safeguard the rights of Polish citizens with respect to their criminal liability). Thus, as a gesture of recognition of EU law supremacy, the Polish Tribunal proposed an amendment of the Polish Code of Criminal Procedure (Article 55) for the purpose of avoiding a potential breach of its obligations under the Treaty. Such an amendment would come from the legislature and would define the application of the EAW towards Polish citizens. Likewise, Cyprus embarked on a constitution revision (Article 11) so as to authorize the extradition of Cypriot nationals for acts committed after its 2004 EU accession. ${ }^{57}$

Almost three months later (18 July 2005), on similar grounds, the German Federal Constitutional Court (Bundesverfassungsgericht; BVerfG hereafter) not only addressed the issue of extradition of its own nationals but also called into question the very foundation of a politically united Europe. ${ }^{58}$ The ruling of the BVerfG did not

\footnotetext{
${ }^{54}$ Summary of judgment available here:

www.trybunal.gov.pl/eng/summaries/summaries_assets/documents/P_1_05_GB.pdf (browsed: 17.10.06).

${ }^{55}$ It was inserted into the Criminal Procedure Code by an amendment (Amendment Act, March 16, 2004) that transposed the Framework Decision on the European Arrest Warrant into the Polish legal system.

${ }^{56}$ The Constitution of the Republic of Poland of $2^{\text {nd }}$ April 1997 as Published in Dziennik Ustaw No.78, item 483. Available at www.sejm.gov.pl/prawo/konst/angielski/konse.htm

${ }^{57}$ Supreme Court of Cyprus, Decision of 7.11.2005, Ap. No 294/2005

${ }^{58}$ Re Constitutionality of German Law Implementing the Framework Decision on a European Arrest Warrant (2 BVR 2236/04), 18 Jul. 2005: [2006] 1 CMLR 16, BVerfGE 113, 273 ff. The case concerned an application by a German national, Mr Mamoun Darkazanli, whose extradition was sought by the Spanish authorities on alleged Al-Qaida terrorist charges. See H. Satzger, 'The German Court and the European Arrest Warrant: "Cryptic Signals" from Karlsruhe', Journal of International Criminal Justice, 4 (4) (2006), 686; T. Konstadinides, 'The Perils of the Europeanisation of Extradition
} 


\section{PROOF VERSION}

declare the EAW unconstitutional. Instead, similarly to the Polish Tribunal, it declared the German national implementation law (EAW Act) to be void. ${ }^{59}$ The BVerfG held that the Framework Decision allows a Member State's judicial authorities to refuse to execute the EAW for offences committed in its territory. Hence, the effect of its ruling was perceived as a short-term blow to European antiterrorism initiatives and a setback to loyal cooperation in the area of police and judicial cooperation in criminal matters. This is because the EAW did not apply in Germany until a new national implementation law was introduced in the form of an Act implementing Article 16 (2) GG. According to the BVerfG, the prohibition of extradition of German nationals laid down in Article 16 (2) GG does not simply embody the duty of a country to safeguard the rights of its nationals but also implies a right, based on the reliability of a legal system which nationals put their faith. This effectively meant that, until a new national implementation law was introduced (in the form of an Act implementing Article 16(2) GG), Germany was allowed - with the endorsement of the BVerfG - to infringe Community law, despite the principle of loyal cooperation.

The BVerfG's ruling, that the EAW Act violated the German Constitution, had a boomerang effect upon German requests for the surrender of non-nationals. Since Germany no longer applied the principle of mutual trust, the national courts of other Member States stressed that, in the absence of a national implementation law on the Framework Decision, there was no legal basis on which the German authorities could rely to apply for extradition under the EAW procedure ${ }^{60}$ Consequently, an amended bill was introduced in the German Bundestag on 24 November 2005, taking into account the objections spelled out by the BVerfG and therefore establishing that each case will be carefully examined to determine whether or not extradition is commensurate. The new transposition law entered into force on 2 August 2006. It reserves, contrary to the Framework Decision, the double criminality test in mixed cases (Auslandsbezug), where the principal part of the offence took place in Germany but the result occurred in a another country.

Of course, this is not to say that all Member States have responded in this German manner to the effective transposition of the Framework Decision. There are cases where actions for constitutional impropriety have been dismissed by domestic courts. ${ }^{61}$ On 3 May 2006 for instance, the Czech Constitutional Court (Ustavni Soud) dismissed an action contesting the EAW implementation legislation, which, according to certain senators and MPs, was unconstitutional on the ground that it abolished the double criminality rule and authorised the extradition of Czech nationals. ${ }^{62}$ The successful argument was that the surrender of nationals forms part of the wider package of obligations contained in the notion of EU Citizenship. Therefore, Czech citizens had to assume both the obligations and rights that went with their status as EU citizens.

\footnotetext{
Procedures in the EU: Mutuality, Fundamental Rights and Constitutional Guarantees', Maastricht Journal of European and Comparative Law, 14 (2007), 179.

${ }^{59}$ The grounds for review were the following: the German citizenship of the wanted person, the protection of the principle of legality and the protection of the principle of recourse to the courts against the grant of extradition [Article 2 (1) and Articles 20 (3), 16(2), and 19 (4) GG (Grundgesetz)]. ${ }^{60}$ Case 2483/2005, Tsokas and Another [2006] CMLR 61 Ar Pag (GR).

${ }^{61}$ See the reasoning of the Areios Pagos (Hellenic Supreme Court of Cassation) in Case No.591/2005, judgment of 08.03.2005.

${ }^{62}$ See 'Judicial Cooperation in Criminal Matters', The Law Societies Joint Brussels Office, Brussels Office Law Reform Update Series (September 2006), p.6.
} 


\section{PROOF VERSION}

The Commission's 2005 Report on the EAW revealed that only half of all Member States had implemented the Framework Decision. ${ }^{63}$ By 2007, however, not only all Member States had implemented it but the Commission reported that legal conflicts 'have been overcome' and 'are no longer an obstacle' to the application of the EAW. ${ }^{64}$ Yet, the abovementioned reviews of the constitutionality of national law implementing the Framework Decision on the EAW stand as reminders to EU Institutions that adverse constitutional responses to the implementation of EU law do not necessarily arise in cases of potential human rights violations but also when fundamental legal principles, inherent deeply in national constitutions, are endangered. ${ }^{65}$ The case of Germany, in particular, reveals the uncertain status of former Third Pillar instruments within national legal orders both in relation to their hierarchy and judicial obligations they entail. Whilst in none of the abovementioned cases did the constitutional courts find it necessary to refer a case to the European Court of Justice, the Court was subsequently asked by the Belgian court to rule on the legality of the Framework Decision in Advocaten voor de Wereld. ${ }^{66}$ There, the system of preliminary reference provided the Court with an opportunity to contribute its part to the resolution of yet another constitutional clash. According to the Court in Advocaten voor de Wereld, the validity of the Framework Decision stems from the fact that the definition of the listed offences constitutes a matter reserved to the Member States. It follows that this does not cause any embarrassing procedural implications in its application, because all Member States must respect fundamental rights.

This bold rhetoric, which gives priority to the Framework Decision's validity over questions of legal certainty, has been harshly criticized, especially in view of the fact that it puts faith in (or creates burden for) in national authorities to respect fundamental rights. Yet it does not foresee any conflict resolution device in case of misapplication. ${ }^{67}$ Others, however, cannot see how the Court could have created such mechanism, given that the preliminary reference in Advocaten voor de Wereld was on an entirely different matter. ${ }^{68}$ Whatever the case, the Court won a battle by declaring that the first legal instrument incorporating the principle of mutual recognition is compatible with fundamental rights. Certainly, the Court paved the way for future developments. Yet, a certain inconsistency has been introduced, partly due to the EU Institutions hesitation in addressing human rights issues that were not raised in the Framework Decision and by the national courts' disinclination to question the protection of fundamental rights in EU law beyond a critique related to the constitutional safeguards against extradition available to their own nationals. Both the definition of the list of offences and the issue of respect for fundamental rights are hereafter described as problem areas. These foreshadow ongoing conflicts between

\footnotetext{
${ }^{63}$ Report from the Commission based on Article 34 of the Council Framework Decision of 13 June 2002 on the European Arrest Warrant and the surrender procedures between Member States (revised version) COM (2006) 8 final, 24.01.2006.

${ }^{64}$ Report from the Commission on the Implementation since 2005 of the Council Decision of 13 June 2002 on the European Arrest Warrant and the Surrender Procedures between Member States, (11.08.2007) COM (2007) 407 final.

${ }^{65}$ See to that effect P. Briza, 'Lucchini SpA - Is there anything left of res judicata principle?', Civil Justice Quarterly, 27 (1) (2008), 40.

${ }^{66}$ Case C-303/05, Advocaten voor de Wereld [2007] ECR I-03633 (see below).

${ }^{67}$ D. Leczykiewicz, 'Constitutional Conflicts and the Third Pillar', European Law Review, 33 (2) (2008), 230; V. Hatzopoulos, 'With or Without You...Judging Politically in the Field of Area of Freedom, Security and Justice', European Law Review, 33(1) (2008), 61.

${ }^{68}$ A. Hinajeros, 'Recent Human Rights Developments in the EU Courts: The Charter of Fundamental Rights, the European Arrest Warrant and Terror Lists', Human Rights Law Review, (2007), 793.
} 


\section{PROOF VERSION}

national constitutional laws and the movement towards enhanced cooperation in criminal matters within the Union.

\subsection{Current Problem Areas}

\subsubsection{The Absence of Definitions in the List of Offences}

The abolition of double criminality was not followed by any kind of European inventory listing disparities in criminal legislation between Member States as to what conduct is punishable. Certain offences such as murder and grievous bodily injury, are obviously understood as offences in any of the twenty-seven Member States. However, many of the thirty-two listed offences do not correspond to defined offences under national law. The lack of definition of the offences in respect of which the safeguard of dual criminality has been abandoned challenges the principle that criminal law must be precise, clear, and predictable, therefore providing one with the knowledge of whether an act constitutes an offence. This is crucial, given that various forms of undesirable conduct as listed in Article 2 (2) of the Framework Decision do not constitute a criminal offence under the laws of some Member States. For instance, most Member States have not criminalized all circumstances in which corruption may occur in the private sector. ${ }^{69}$ It further creates problems that neither Article 2 (2) nor other provisions of the Framework Decision contain definitions of the listed offences.

According to the European Court of Justice, the answer to the question of whether the EAW can be utilized in a case at hand depends on the definitions supplied by the criminal law of the issuing Member State regarding the offences in question. This is rather challenging to Member States, especially where the offence in question (e.g. computer crime) does not satisfy the requirements typically applicable to offences under national criminal law. The differences between Member States' criminal legal systems in assessing the severity of a crime (drug trafficking, ${ }^{70}$ euthanasia / assisted suicide $^{71}$ abortion $^{72}$ or spying / plane-spotting inside a military zone, ${ }^{73}$ to name but a few) are obvious. For instance, Belgium has excluded (in its implementation law) the possibility of issuing a EAW in respect of a request pertaining to euthanasia or abortion. $^{74}$

In Advocaten voor de Wereld, ${ }^{75}$ the Court supported the view that because harmonization of national criminal law is not a precondition for the application of the EAW, the absence of definitions does not imply an inconsistency with the principles of equality and legality in criminal proceedings. Indisputably, the Court's minimalist

\footnotetext{
${ }^{69}$ European Commission Report to the Council based on Article 9 of the Council Framework Decision 2003/568/JHA of 22 July 2003 on Combating Corruption in the Private Sector, (18.06.2007) COM (2007) 328.

${ }^{70}$ C. Chatwin, 'Drug Policy Developments within the European Union: the Destabilizing Effects of Dutch and Swedish Drug Policies', British Journal of Criminology, 43 (2003), 567.

${ }^{71}$ See The Queen on the Application of Mrs Dianne Pretty v. Director of Public Prosecutions and Secretary of State for the Home Department [2002] 1 A.C. 800.

${ }^{72}$ See J. English and R. Card, Police Law, $9^{\text {th }}$ edn (Oxford University Press, 2005), especially 30. Homicide and Abortion.

${ }^{73}$ See 'Greece Holds Plain-Spotting Spies', Available at BBC: http://news.bbc.co.uk/onthisday/hi/dates/stories/november/12/newsid_2518000/2518385.stm

${ }^{74}$ See N.N. Shuibhne, 'Margins of Appreciation: National Values, Fundamental Rights and EC Free Movement Law', European Law Review, 34 (2) (2009), 252.

${ }^{75}$ Case C-303/05, Advocaten voor de Wereld [2007] ECR I-03633. In its judgment, the Court confirmed the legality of the Framework Decision on the EAW, commenting that the measure, which aims at simplifying the extradition procedure, could be adopted in the form of a Framework Decision.
} 


\section{PROOF VERSION}

approach in Advocaten voor de Wereld saved the Framework Decision from national challenges on the ground of lack of competence. By contrast in Kozlowski, the Court did not leave it to the Member States to define the terms 'staying' and 'residence' in order to determine the scope of Article 4 (6) of the Framework Decision (optional non-execution of a EAW). It rather held that both terms could not be defined unilaterally, especially because they concern 'autonomous concepts of Union law' ${ }^{76}$ Equally, in Wolzenburg the Court established that a Member State cannot make the ground for optional non-execution subject to an indefinite residence permit, especially since the 'Citizenship' Directive 2004/38 (Article 16(1)) does not impose such a requirement. ${ }^{77}$ One, however, cannot tolerate the fact that the lack of precise definition of the listed extraditable offences carries the potential of divergent implementation of the Framework Decision within the legal orders of the twenty-seven Member States. An example may clarify this argument. Although Greek law does not establish a clear distinction between possession of drugs for personal use and for trafficking, in the cases of Zanotti and d'Orsi the Greek courts issued a EAW against two Italian youths caught in possession of a small quantity of cannabis (21 grams) under the charge of international trafficking, transportation, and possession-for-sale of drugs. Italy, in this case, complied with the EAW, and because Greece does not have a law in place for trials in absentia, the two offenders had to suffer imprisonment until judgment was passed at first instance and before their release on bail. ${ }^{78}$

The absence of pan-European definitions in relation to extraditable offences obliges, in principle, Member States to extradite individuals on suspicion of committing an offence that might not be a crime in most Member States. The Framework Decision's sloppy drafting is particularly relevant in the spectre of 'thought' or 'opinion' crimes, such as racism and xenophobia, which, although they are designated in Article 2 of the Framework Decision, are nonetheless treated differently by Member States. For instance, in the so-called Elsinore case, Denmark honored Germany's extradition order against Stefan Günther and Flemming Christiansen, a German and a Danish citizen respectively. The crimes of which they were being charged (distribution of Nazi music to the German market), although relentlessly prosecuted in Germany are dealt with in Denmark, depending on evidence, by a warning, a pecuniary fine, or a short suspended prison sentence. ${ }^{79}$ This, however, did not stop the Danish authorities from complying with the issued EAW. Sweden, on the other hand, where the capacity to enforce such laws is rather weak, did not comply with Germany's request to extradite a Danish citizen, who had been accomplice to the selling Nazi music to Germany. ${ }^{80}$

Another noteworthy example exposing the disparities in the definition of what constitutes a 'thought crime' in the Member States is the case of Fredrick Töben. ${ }^{81}$

\footnotetext{
${ }^{76}$ Case C-66/08, Szymon Kozlowski [2008] ECR 00000, para 43.

${ }^{77}$ Case C-123/08, Dominic Wolzenburg [2009] ECR 00000.

${ }^{78}$ Written Question by Marco Cappato and Marco Pannella (ALDE) to the Commission, 'Extradition and Pre-Trial Detention of Two Italian Youths, and the European Arrest Warrant', 22.09.2008, E4980/08. See some hypothetical examples in R. Blextoon, 'The European Arrest Warrant, Disaster in Disguise (A Parcticians View), Paper presented at the ECBA conference, Paris, 01.05.2004. Available at www.ecba.org

79 'Danmark udleverer nazimusikere til Tyskland', Politiken, (20.02.2009). Available at http://politiken.dk/indland/article654174.ece

Furthermore, Germany, maintains strict laws about Holocaust denial, an offence punishable by a term of three years. This has also raised concerns in the UK. See Hansard, HL Deb 23 April 2002, vol 634, cc206-36.

80 'JK ogillar utlämning av dansk nazist', Sydsvenskan, 14.11.2008.

81 'Holocaust denier Fredrick Toben wins German extradition fight', The Times, 20.11.2008.
} 


\section{PROOF VERSION}

Töben, an Australian academic and holocaust denier, who was arrested and remanded in custody in the UK after a German bid to have him extradited for posting antiSemitic and revisionist information on his privately-funded Adelaide Institute internet website. Had he been extradited to Germany by the British authorities he would have been convicted under Section 130 of the German criminal code of criminal contempt and could have served up to a five-year custodial sentence as a political conscience prisoner. The Westminster Magistrates' Court, however, discharged the extradition process by declaring the particulars of the warrant vague and imprecise and therefore the EAW to be invalid. The above examples only serve as illustrations of the profound tribulations experienced due to the abolition of the 'double criminality' test and the lack of definitions of the listed offences in Article 2 (2) of the Framework Decision. These deficiencies expose immense dangers to the desired process of swifter extradition all in the name of permissible freedom of speech and academic freedom within the EU.

Through the adoption of corresponding framework decisions, the Council has implicitly filled in certain gaps left open by Article 2 (2) of the Framework Decision by either setting out common definitions of criminal (and extraditable) offences or by offering guidance as to the level of approximation of laws demanded of Member States. Framework Decision 2008/841/JHA, ${ }^{82}$ for instance, provides that the definition of offences relating to participation in a criminal organization should be approximated in the Member States. Article 1 of the Framework Decision provides that:

criminal organisation' means a structured association, established over a period of time, of more than two persons acting in concert with a view to committing offences which are punishable by deprivation of liberty or a detention order of a maximum of at least four years, or a more serious penalty, to obtain, directly or indirectly, a financial or other material benefit.

Additionally, Framework Decision 2008/913/JHA ${ }^{83}$ provides Member States with detailed guidance as to the kind of intentional conduct that amounts to 'racism' and 'xenophobia' and should therefore be punishable under national criminal law. This, contrary to an executing state's own evaluation as to whether the conditions sufficiently comply with an extradition request, as per Elsinore or Töben, creates the basis for an almost automatic compliance with an issuing state's demands to persecute individuals even on the basis of academic or artistic expressions of historical revisionism. ${ }^{84}$ Equally, Framework Decision 2008/919/JHA provides a list of new offences linked to terrorist activities. These are, according to Article 1 of the Framework Decision: public provocation to commit a terrorist offence; recruitment for terrorism; and training for terrorism.

In line with the spirit of the Court's decision in Advocaten voor de Wereld, harmonisation is not a pre-condition to the application of the principle of mutual recognition. Mutual recognition is, however, easier said than done. The EU Institutions seem to have acknowledged this through the increasing adoption of framework decisions. It can be argued that, notwithstanding the importance of mutual recognition as a central principle in European criminal law, its utilization without, where necessary, the aid of approximation counteracts efforts to overcome obstacles for efficient judicial cooperation. Such obstacles are created by the divergence of

\footnotetext{
82 (11.11.2008) OJ L 300.

83 (9.12.2008) OJ L 330.

${ }^{84}$ See Gregorius Nekschot Speech at the Danish Free Press Society, Trykkefrihedsselskabet, (3.02.2009). Available at EuropeNews http://europenews.dk/en/node/19330.
} 


\section{PROOF VERSION}

legal approaches in the Member States. As this last sentiment illustrates, the objective of combating crimes, which pay no regard to national territorial boundaries, appears to legitimize further EU intervention. This approach fails to acknowledge, however, national choice and penal cultures. It also takes too lightly the fact that the Europeanisation of criminal law creates the potential for diminishing the traditional limits of sovereignty between Member States.

As the above examples illustrate, some Member States find it ludicrous extradite suspects who have not, in their own eyes, engaged in criminal behaviour. Yet, in view of the ever-growing cross-border mobility of EU citizens, the lowering of internal borders, and the rapid development of electronic communication, compulsory prosecution constitutes for other Member States a way of combating cross-border crime. However, this hides a danger. There could be the emergence of instances where the exercise of state power over the citizen goes beyond the threshold set by the Framework Decision. For instance, issuing authorities often fail to apply a 'proportionality' test during the issuing stage of the EAW. But, respondent authorities do not have a discretion to deny surrendering a person on the grounds of the triviality of the alleged offence, if it carries minimum custodial sentences. ${ }^{85}$ Poland has already issued EAWs for offences, which although falling within the scope of Article 2 of the Framework Decision, are nevertheless not serious enough to justify the measures, which the execution of a EAW requires. ${ }^{86}$

In Zak v. Regional Court of Bydgoszcz, Poland ${ }^{87}$ the offence for which extradition was sought, though described in the EAW as 'unintentional receiving of stolen property', was only a mobile telephone. Although the High Court of England and Wales cast doubts on whether the conduct described in the warrant included the elements of belief or suspicion as to the mobile telephone being stolen, and was also sceptical as to whether it amounted to an extradition offence or an offence under English law (it did not hesitate to refer to the alleged offence as a trivial one) it upheld the order for extradition. One might argue that the implementation by all Member States of the recent Framework Decision applying the principle of mutual recognition to financial penalties ${ }^{88}$ might now reduce the volume of such cases. Yet, according to Article 5, the Framework Decision operates without any need for double criminality. What may appear to be a minor offence in the executing state may not be in the requesting state.

The possibility under EU law for a citizen to be extradited to another Member State for an act committed and considered lawful in his/her own Member State, confirms that national criminal law is being stripped of its practical effect of

\footnotetext{
${ }^{85}$ See R. Davidson, 'A Sledgehammer to Crack a Nut? Should There be a Bar of Triviality in European Arrest Warrant Cases?', Criminal Law Review, 1 (2009), 33.

${ }^{86}$ In 2006, Poland issued 2421 EAWs, of which only 235 were executed. See Council of the EU, 'Evaluation Report on the fourth round of mutual evaluations "the practical application of the European arrest warrant and corresponding surrender procedures between member states" Report on Poland', Brussels, 7.02.2008, 14240/2/07 REV 2, p.67. In 2007, respectively, Poland issued most EAWs reaching the number of 3473. See European Parliament, DG Internal Policies of the Union, Policy Department C: Citizens' Rights and Constitutional Affairs, 'Implementation of the European Arrest Warrant and Joint Investigation Teams at EU and National Levels', January 2009, PE 410.671, p.15.

${ }^{87}$ [2008] EWHC 470. See more national reports in the 'Analysis of the Future of Mutual Recognition in Criminal Matters in the European Union', available at the ECLAN web page: www.ulb.ac.be/iee/penal/mutualrecognition/.

${ }^{88}$ Council Framework Decision 2005/214/JHA of 24 February 2005 on the application of mutual recognition to financial penalties OJ L 076. The Criminal Justice and Immigration Bill received Royal Assent on 08.05.2008, with the result that the Framework Decision was transposed to UK law. Currently only one third of the Member States have implemented the Framework Decision.
} 


\section{PROOF VERSION}

safeguarding the well-being of the nation state against threats from overseas. Similarly, it is not feasible for a citizen of one Member State to be aware that her/his actions performed in good faith in another Member State might be punishable. This may raise concerns not only among the most Euro-sceptic, alleging that law-abiding citizens may soon end up with a criminal record for non-compliance with laws that defy common sense, especially as ignorance of the law is no defence.

\subsubsection{Mutual Recognition and Mutual Trust: The Case of Fundamental Rights}

As previous arguments suggest, it is apparent that the idealism encompassed in the implementation of the principle of mutual recognition is not blatantly obvious in the sensitive area of police and judicial cooperation in criminal matters. This is perhaps the underlining reason behind the hesitance of the European Council at Tampere to condition the implementation to mutual recognition. Despite the notable progress at EU level in relation to judicial cooperation, exchange of information and monitoring, ${ }^{89}$ intergovernmental legislative mechanisms are still, to a certain extent, remote from the supranational level, even on basic issues such as access to justice. Because a person's rights in respect of a criminal charge, trial, and sentence are strictly confined within the national boundaries of Member States the mutual recognition threshold will have to depend on a high level of trust between judicial authorities. There will also have to be procedural rules which respond to equivalent guarantees in relation to an individual's liberty.

Fair Trials International, ${ }^{90}$ reporting on certain individual cases, has highlighted the diverse practices in the application of justice across the European Union. ${ }^{91}$ In the context of the EAW, there is no common agenda for legal rights to be activated once the procedure under the Framework Decision has been triggered. It appears that mutual judicial cooperation in criminal matters cannot operate alone without efficient cross-border criminal cooperation measures. For instance, as regards legal aid, there is no mechanism under which defence lawyers in either country can coordinate or jointly evaluate the evidence available throughout judicial proceedings. Furthermore, the right to legal representation varies among Member States. Individuals will reach a point where they need to cover the costs of legal advice and translation services and deal with delays during their transfer from the responding state to the requesting state. $^{92}$

What is more, the adoption and implementation of minimum standards of procedural rights across the Member States never formed a precondition to the

\footnotetext{
${ }^{89}$ Council Framework Decision of 13 June 2002 on Joint Investigation Teams 2002/465/JHA OJ L 162; Council Framework Decision 2005/876/JHA of 21 November 2005 on the Exchange of Information Extracted from the Criminal Record OJ L 322; Council Framework Decision 2008/977/JHA of 27 November 2008 on the protection of personal data processed in the framework of police and judicial cooperation in criminal matters OJ L 350/60; Council Framework Decision 2008/978/JHA of 18 December 2008 on the European Evidence Warrant for the purpose of obtaining objects, documents and data for use in proceedings in criminal matters OJ L 350/72; Commission Green Paper on obtaining evidence in criminal matters from one Member State to another and securing its admissibility, 11.11.2009, COM (2009) 624 Final.

${ }^{90}$ Fair Trials International is an NGO working to ensure that citizens accused of a crime in a state other than their native receive a fair trial according to international standards of justice.

${ }^{91}$ See more recent cases: Andrew Symeou, February 2009; Klaas Jan Bolt, April 2008; Luke Atkinson and Michael Binnington, February 2008. Available at www.fairtrials.net, Cases, Spotlight Archive. See also Fair Trials International, Annual Review 2006-07; Fair Trials International, Submission on the Future EU Justice Programme for 2010-1014, December 2008, also Available at www.fairtrials.net.

${ }^{92}$ See for reference Kakis v. Government of the Republic of Cyprus [1978] 1 WLR 772 HL.
} 


\section{PROOF VERSION}

adoption of the Framework Decision on the EAW. According to the principle of mutual recognition, Member States shall meet the standards of human rights protection set out in the European Convention on Human Rights (ECHR) ${ }^{93}$ This also constitutes a Treaty obligation under Article 6 TEU. A reference to 'respect for fundamental rights' is made in the Preamble (Paragraphs 12; 13) and Article 1(3) of the Framework Decision. ${ }^{94}$ However, the 'in absentia' rules of Articles 35 of the Framework Decision do not allow a person to request a new trial on grounds that $\mathrm{s} / \mathrm{he}$ was inadequately represented at the initial trial. ${ }^{95}$ This contradicts the Court's decision in Krombach v. Bamberski, ${ }^{96}$ where, in the light of the ECHR, the Court expressly recognized the general principle that everyone is entitled to fair legal process. ${ }^{97}$ The Court upheld the decision of a German court (refusing on public policy grounds recognition and enforcement of a French judgment) due to the fact that the German defendant was denied legal representation at his trial before the assize court, which had condemned him in absentia on a civil claim for damages. According to Article 6 (3) ECHR, free legal assistance and access to court is guaranteed for the accused in criminal proceedings. This applies, according to the European Court of Human Rights (EctHR) in Croissant v. Germany ${ }^{98}$, to the entire proceedings, including the pre-trial proceedings, the trial stage, the appellate proceedings and the cassation proceedings. This is to ensure that rights are 'practical' and effective and not theoretical and illusory. ${ }^{99}$

In Advocaten voor de Wereld the Court submitted that the principles of equality and non-discrimination bind all Member States and that differential treatment can only be objectively justified given the seriousness of the listed offences. The Court failed to make a comparison between the system under the Framework Decision on the EAW and the old procedure based on the double criminality test with reference to differential treatment. Hence, it is still unclear whether the application of the right to a fair trial; the right to legal aid and the route of appeal (or judicial review) in cases of breaches of safeguards in the issuing Member State can be secured in the absence of a European habeas corpus. The Framework Decision does not oblige Member States to refuse surrender on grounds of valid concerns about violations of the EU dual source of human rights streaming from the ECHR and the constitutional traditions of the Member States. ${ }^{100}$ In any case, the application of the principle of mutual recognition diminishes a national judge's discretion to refuse extradition of a suspect who, for instance, has been convicted in absentia, even in cases where the judge is concerned

\footnotetext{
${ }_{93}^{9}$ Available at www.hri.org/docs/ECHR50.html.

${ }^{94}$ Preamble (12): This Framework Decision respects fundamental rights and observes the principles recognised by Article 6 of the Treaty on European Union and reflected in the Charter of Fundamental Rights of the European Union (7), in particular Chapter VI thereof.

Preamble (13): No person should be removed, expelled or extradited to a State where there is a serious risk that he or she would be subjected to the death penalty, torture or other inhuman or degrading treatment or punishment.

Article 1(3): This Framework Decision shall not have the effect of modifying the obligation to respect fundamental rights and fundamental legal principles as enshrined in Article 6 of the Treaty on European Union.

${ }^{95}$ Raffaele Caldarelli v. The Court of Naples, Italy [2007] EWHC 1624.

${ }^{96}$ Case C-7/98 Krombach v. Bamberski [2001] All ER (EC) 584.

${ }^{97}$ Case C-185/95 Baustahlgewebe v. Commission [1998] ECR I-8417 (at para 20, 21); C174/98 \& C189/98 Netherlands and Van der Wal v. Commission [2000] ECR I-0000 (at para 17).

${ }^{98}$ Croissant v. Germany (1992) 16 EHRR 135.

${ }^{99}$ Delcourt v. Belgium (1970) 1 EHRR 355.

${ }^{100}$ Article 6(2) TEU.
} 


\section{PROOF VERSION}

as to the violation of the suspect's rights, for example the right to family life under Article 8 ECHR. ${ }^{101}$ All in all the merits of the extradition request are to be taken:

...on trust and not investigated by the Member State from which extradition was sought.... Any inquiry by a member state into the merits of a proposed prosecution in another member state or into the soundness of a conviction in another member state becomes, therefore, inappropriate and unwarranted. It would be inconsistent with the principle of mutual respect and recognition of the judicial decisions in that member state. ${ }^{102}$

Alegre and Leaf comment that the assumption that Member States meet the ECHR standards 'is open to discussion as, while it is true that all Member States and candidate countries have signed up to the ECHR, all have had and continue to have judgments against them in the Court of Human Rights. ${ }^{103}$ Allegedly, this would have a negative impact upon imminent individual claims that an issuing state is violating fundamental rights, such as review to detention (Article 5 ECHR) and the right to fair trial (Article 6 ECHR; Art. 47 of the European Charter of Fundamental Rights). ${ }^{104}$ Yet, it would be naïve to assume that mutual trust is built solely on the fact that all Member States are signatories to the ECHR. ${ }^{105}$ As a result, the margin of appreciation in the application of rights safeguarded by the ECHR relating to the domestic administration of justice is difficult to sustain. Even prior to the implementation of the European Evidence Warrant ${ }^{106}$ the admissibility of evidence extracted through torture or ill-treatment (and the allegations of torture or ill-treatment by law enforcement officers) constituted major barriers to mutual trust between Member States and were, of course, infringements of Art 6 ECHR.

In Ramda, ${ }^{107}$, ill-treatment and bodily harm was inflicted on the suspected offender by the French Police during an intense interrogation procedure. The French authorities denied an investigation of the complaints of ill-treatment contrary to the request of the British Court. Thus the Secretary of State refused to surrender the suspected offender because 'it is unlawful for a public authority, such as the Secretary of State, to act in a way which is incompatible with a Convention (ECHR) right, and of course Article 6(1) ECHR provides for the right to a fair trial. The test appears to be whether the evidence establishes a real risk of a flagrant denial of justice. ${ }^{108}$ Similarly, in the French case of Irastorza Dorronsoro ${ }^{109}$ the admissibility of evidence allegedly extracted from an ETA suspect through torture or other ill-treatment was considered contrary to a state's obligations under the UN Convention Against Torture and Other Cruel, Inhuman or Degrading Treatment or Punishment (1984). ${ }^{110}$

\footnotetext{
${ }^{101}$ See Zak v. Regional Court of Bydgoszcz, Poland [2008] EWHC 470.

${ }^{102}$ See Hilali (Application for a Writ of Habeas Corpus) [2008] UKHL 3, para 14.

103 S. Alegre and M. Leaf, 'Judicial Cooperation: A Step too Far Too Soon? Case Study - The European Arrest Warrant', European Law Journal, 10 (2) (2004), 201.

${ }^{104}$ C364/8 (2000).

105 Ibid., para 154.

106 Council Framework Decision 2008/978/JHA of 18 December 2008 on the European Evidence Warrant for the purpose of obtaining objects, documents and data for use in proceedings in criminal matters OJ L 350/72.

${ }^{107}$ Rachid Ramda v. Secretary of State for the Home Department, The Government of France [2005] EWHC 2626 (Admin).

${ }^{108}$ Ibid., at para 19.

${ }^{109}$ No 238/2003 Irrastorza Dorronsoro, judgment of 16.05.2 003, Cour d'Appel de Pau (France).

${ }^{110}$ Available at www2.ohchr.org/english/law/pdf/cat.pdf.
} 
The outcome of both cases emphasizes the need to address the issue of the, often justified, lack of mutual trust in national procedural guarantees within the Union. It is worth mentioning that because the Framework Decision is binding only as to the end result, leaving the choice of form and method of implementation to Member States, the UK has inserted a human rights clause in its Extradition Act 2003. The executing judge thereby has the authority to deny the extradition of a person on grounds of incompatibility with the Human Rights Act $1998 .{ }^{111}$ Yet it should be mentioned that the ECHR allows signatory states to suspend / derogate from certain Convention obligations (Article 5) when they face a severe national emergency. After the terrorist attacks in the USA on September 11, 2002, the UK has used derogations as to the length of time alleged international terrorists may be detained (without charge) before being brought to trial on grounds of national security. Pre-trial detention is covered in the Commission's Green Paper on Mutual Recognition of Non-Custodial Pre-Trial Supervision Measures 2004, which treats custody pending trial as 'an exceptional measure' and proposes 'the introduction of a legal instrument enabling the Member States of the European Union to mutually recognise non-custodial pre-trial supervision measures'. ${ }^{112}$

For the same purpose, the Commission issued a Communication to the Council and to the European Parliament on the 'Mutual Recognition of Judicial Decisions in Criminal Matters and the Strengthening of Mutual Trust between Member States'. ${ }^{113}$ The Commission's review of several aspects of the pre-trial stage (such as mutual recognition of evidence and pre-trial supervision measures) concludes that mutually recognised judgments along with further approximation of criminal law secure human rights such as the presumption of innocence, restrictions on decisions in absentia, and minimum standards on the gathering of evidence. Following the coming into force of the Treaty of Lisbon, it remains to be seen how the Court will apply the now binding EU Charter of Fundamental Rights as a means of managing national and international standards of fundamental rights protection. We cannot yet know whether the Court will be able to ensure that procedural safeguards for individuals are effectively controlled in a so-called 'European penal area'. As the current position stands, it is only a matter of time before such cases will be referred to the European Court of Human Rights.

\subsection{Conclusion}

Despite criticisms that European criminal law suffers from a lack of any uniform definition of a crime, as well as a lack of mutually accepted procedural requirements, it can be argued that the adoption of the Framework Decision on the EAW constitutes a step towards the creation of an effective area of freedom, security and justice. Indeed mutual recognition comforts those opposing harmonization in criminal matters. It is, according to Mitsilegas, "handy as it can provide results for judges and prosecutors when cooperating across borders... while prima facie Member States do not have to change their domestic criminal law to implement EU standards'. ${ }^{114}$ The problem, however, with mutual recognition as a prerequisite for the successful application of the Framework Decision on the EAW lies in the many variations in its

\footnotetext{
111 See $R$ (on application of Bermingham and others) v. Director of the Serious Fraud Office; Bermingham and others v. Government of the United States of America [2006] All ER 239, at para 4.

${ }^{112}$ COM (2004) 562.

${ }^{113}$ COM (2005) 195.

${ }^{114}$ V. Mitsilegas, 'The Constitutional Implications of Mutual Recognition in Criminal Matters in the EU', Common Market Law Review, 43 (2006), 1280.
} 


\section{PROOF VERSION}

implementation. This diversity has led, in certain previously discussed cases, to a twotier system. ${ }^{115}$ It can be submitted that the abolition of double criminality and the removal of bars to the surrender of one's own nationals would have been met with applause had national criminal codes been subject to supranational harmonisation. As Geyer wryly observes: 'if the principle of mutual recognition in criminal matters was regarded as an alternative to harmonisation of criminal law, why should member states still be allowed a legal instrument for the purpose? 116

The Treaty of Lisbon has brought former Third Pillar provisions under a common general legal framework. Under Article 82 TFEU mutual recognition and approximation of laws form the basis for criminal judicial co-operation. Accordingly, Article 83 TFEU provides that measures in the area of police and judicial cooperation in criminal matters shall take the form of Regulations and Directives and therefore may confer directly effective rights upon individuals, justiciable before their national courts. It follows, therefore, that it is a matter of time that the Framework Decision on the EAW will be converted to a Directive. EU involvement in the area of criminal law will thus contribute to the furtherance of supranational actions and objectives while alleviating the past concerns about the lack of democratic legitimacy in the former Third Pillar. ${ }^{117}$ Yet, it would be foolhardy to assume that the Communitarization of the Third Pillar would lead to uniformity through evaporation of national vetoes and controls over criminal law. The adoption, implementation, and application of the Framework Decision on the EAW, or else the Europeanisation of extradition expose the intimate areas of sovereignty covered by the former Third Pillar. Indeed, the principle of mutual recognition has surmounted the danger of being challenged because of the alleged lack of genuine mutual confidence between Member States. Yet, there is lot more to be done. ${ }^{118}$ The choice between a robust European criminal justice policy and reconciliation of diverse national values calls for a prior reconciliation of national legislation and national constitutions.

The argument against the legitimization of further European action in the field of criminal law entails the orthodox view that neither criminal law nor the rules of criminal procedure and police and judicial cooperation fall within the competence of the Union. ${ }^{119}$ This concerns, in particular, horizontal criminal law measures falling under Title $\mathrm{V}$ of the TFEU. This argument takes into account both the principle of subsidiarity and diversity in national penal systems. In his dissenting Opinion in Re Constitutionality of German Law Implementing the Framework Decision on a $E A W{ }^{120}$ Judge Brob considered the violation of the principle of subsidiarity as the main factor for declaring the German EAW Act unconstitutional. Behind Judge Brob's opinion lied the idea that the centralisation of competence at EU level would limit the ability of the Member States to guarantee constitutional rights currently enjoyed by their citizens. If, therefore, the Communitarisation of judicial cooperation throughout the EU is a step in the direction of a European Federal State, then any

\footnotetext{
${ }^{115}$ E. van Sliedregt, 'The European Arrest Warrant: Between Trust, Democracy and the Rule of Law', European Constitutional Law Review, 3 (2007), 244.

${ }^{116}$ F. Geyer, 'Case Note: Advocaten voor de Wereld', European Constitutional Law Review, 4 (2008), 154.

${ }^{117}$ See E. Herlin-Karnell, 'In the Wake of Pupino: Advocaten voor der Wereld and Dell'Orto', German Law Journal, 8 (12) (2007), 1148.

${ }^{118}$ See Council of the European Union, 'Final Report on the Fourth Round of Mutual Evaluations The practical application of the European Arrest Warrant and Corresponding Surrender Procedures between Member States', 28 May 2009, 8302/4/09 REV 4.

${ }^{119}$ Case 203/80, Casati [1981] ECR 2595, para 27; Case C-226/97, Lemmens [1998] ECR I-3711, para 19; Case C-176/03, Commission v. Council [2005] ECR I-7879 para 47.

${ }^{120}$ [2006] 1 CMLR 16, BVerfGE 113, $273 \mathrm{ff}$.
} 


\section{PROOF VERSION}

concerns related to violations of subsidiarity are rational. An unprecedented harmonisation of national legislation may result in unconstitutional amendments of national constitutional provisions. Accordingly, there are limits to supranational criminal law insofar as EU law can only require national competent authorities to impose effective, dissuasive and proportionate criminal penalties against persons who have committed one of the prescribed offences referred to in the relevant provision. It does not determine the type and level of sanctions to be imposed. However, although the Union's competence can go as far as condemning particular offences, the diversity of definitions regarding the same conduct in the Member States can cause problems. While encompassing many important points and issues, the abovementioned arguments can be said, at best, to provide only partial accounts of the future state of European criminal law. 